\title{
Habitat use by an intertidal salt-marsh fish: trade-offs between predation and growth
}

\author{
Patricia M. Halpin* \\ Program in Ecology and Evolutionary Biology, Brown University, Providence, Rhode Island 02912, USA
}

\begin{abstract}
Biological and physical factors interact to determine habitat use by animals. While sessile organisms inhabiting intertidal areas have been well studied, the processes underlying the use of intertidal areas by highly mobile animals such as fishes remain poorly understood. This study examines whether an intertidal fish, the mummichog Fundwlus heteroclitus, preferentially uses habitats where growth rate is maximized or, like most sessile animals, is restricted to habitats providing escape from strong negative biological interactions but compromising growth. 1 compared growth rates and predation rates on adult $F$. heteroclitus at 3 Rhode Island salt marshes in 2 seasons (summer and fall). Salt marshes varied in the types of habitat (creek, pond, channel, mudflat) available to fishes within each marsh. Growth rates of marked mummichogs held in cages were determined in each habitat and each marsh for $6 \mathrm{wk}$. Predation risk was assessed by determining mortality of $F$. heteroclitus tethered in each habitat in each of the 2 seasons. Habitat use was quantified by trapping fish in each habitat in each season. Both growth rate and predation risk influenced habitat use by $F$. heteroclitus in these intertidal salt marshes. Overall, salt marshes offered opportunities for both higher growth rates and shelter from predation compared to areas outside salt marshes. However, mummichogs often faced trade-offs between predation refuge and growth in specific habitat types. When predation risk was high across all habitat types in a marsh, habitats associated with the highest growth rates were used. If a predation refuge was available, habitat use increased, even when growth rates in the habitat were low. A habitat characterized by both shelter and high growth rates, e.g. Coggeshall Cove ponds in fall, were used almost exclusively. Variation in quality of the same habitat type in different marshes led to differences in overall marsh quality. Determination of profitability of habitat for fishes cannot be assessed through habitat use alone; measurement of factors, such as predation risk and growth, which influence habitat quality are also necessary.
\end{abstract}

KEY WORDS: Habitat use - Mobile species - Salt marsh - Predation · Predation risk - Ecological tradeoffs $\cdot$ Intertidal fish $\cdot$ Habitat quality

\section{INTRODUCTION}

Animals and plants frequently face trade-offs between their requirements for maximizing growth and minimizing mortality risk. The ideal free distribution (IFD) theory (Fretwell \& Lucas 1970) predicts that organisms will forage in those habitats that provide the highest energetic return as mediated by intraspecific competition. These habitats can be thought of as physiological optima, i.e. physical and biological conditions are such

\footnotetext{
- Present address: Department of Zoology, Oregon State University, Corvallis, Oregon 97331, USA.

E-mail: halpinp@bcc.orst.edu
}

that organism growth is maximized. IFD models have commonly been applied to mobile animals (review: Tregenza 1995). While IFD models have produced mixed results in laboratory and some field situations, most researchers have found that an organism's ability to forage optimally is frequently thwarted by strong negative interactions with competitors and predators (Werner et al. 1983, Jefferies \& Lawton 1984, Milinski 1986, Holbrook \& Schmitt 1988a, Werner \& Hall 1988, Lima \& Dill 1990, Peckarsky et al. 1993, Turner 1996).

Nowhere have foraging models such as the IFD been more controversial than in intertidal ecology. Intertidal areas such as rocky shores and salt marshes have often been used as general models for ecological interac- 
tions because of the ease of experimentation on sessile organisms with restricted distributions. As in other ecosystems, early ecological theory assumed that the distribution patterns of intertidal species resulted from species segregating according to physiological optima (Lewis 1963, Newell 1979). Over 30 yr ago, ecologists challenged this idea by performing field experiments that moved organisms into areas outside their normal ranges. From these and similar experiments it was concluded that most intertidal organisms inhabit physiological refugia and are excluded from areas of physiological 'optima'. Many intertidal habitats provide refuge from competition and predation that exclude sessile animals from lower zones (reviews: Connell 1972, Underwood et al. 1983, Underwood \& Denley 1984, Menge \& Sutherland 1987). These studies indicated that organisms were seldom able to select habitats based on energetic return. However, this discrepancy may be related to the preference of sessile organisms as study subjects in the intertidal.

Sessile animals can only enter habitats through recruitment and leave them through death. Mobile animals may abandon and recolonize habitats on a tidal, diurnal, or seasonal basis without suffering mortality. Therefore, the population dynamics and regulatory processes of sessile organisms could dramatically differ from those of highly mobile organisms because of the ability of mobile animals to rapidly respond to environmental change (Breitburg 1992).

Within the intertidal, 'resident' fishes remain in intertidal areas at low tide and are rarely found in the subtidal (Gibson 1969); they are thus permanently exposed to the extreme physical conditions associated with intertidal habitats. Within salt marshes at low tide, resident fishes remain in a variety of habitats such as ponds, creeks, mudflats and large channels, where water remains available until return of the flood tide. If resident intertidal fish populations are structured in the same manner as their sessile intertidal counterparts, then predation or competition will exclude them from those habitats in which their growth rates would otherwise be maximized. Alternatively, because of their high mobility, fishes may be able respond to environmental change and use those habitats in which their growth is maximized. This study examined mummichogs inhabiting intertidal salt marshes, because (1) they can serve as a general model of highly mobile animals within intertidal areas, and (2) salt marshes are important ecosystems. Since salt marshes serve as nursery grounds for many species, an understanding of the processes governing fish dynamics is essential (Weinstein 1979, Bozeman \& Dean 1980, Boesch \& Turner 1984, Rogers et al. 1984). Fish populations of salt marshes constitute an important energetic link between the marsh and the open sea (Nixon \& Oviatt
1973). Therefore, to fully understand intertidal fish ecology, we must also investigate variations in habitat use within the intertidal.

The mummichog Fundulus heteroclitus is a resident species of intertidal salt marshes on the east coast of North America (Bigelow \& Schroeder 1953, Halpin 1997). It remains in the marsh at low tide, in water retained within the marsh. From fall to spring, mummichogs concentrate in high intertidal habitats such as ponds and creeks in the marsh meadow. In summer when their abundance is highest, channel and mudflat habitats are also used intensively (Halpin 1997 and unpubl. data). Mummichog growth has been studied extensively both in the laboratory and in the field. Field estimates of growth have been provided by population censuses and caging studies (Wright 1972, Kneib \& Stiven 1978, Kneib 1981, Weisberg \& Lotrich 1982,1986 , Weisberg 1986). No study so far has compared growth rates across the range of marsh habitats (e.g. ponds and mudflats) or determined growth rates of $F$. heteroclitus outside its normal distribution areas.

Salt-marsh fishes have been reported to alter their habitat use in response to predation. In a New Jersey salt marsh, McIvor \& Odum (1988) demonstrated that at low tide Fundulus spp. occupied 'erosional' areas of water channels where predation was low but food resources were scarce. Juvenile F. heteroclitus in Georgia salt marshes are restricted to habitats where adult conspecifics cannot cannibalize them (Kneib 1987).

This study examines the influence of the trade-off between growth rate and predation risk on habitat use by the mummichog Fundulus heteroclitus. The null hypothesis, $H_{0}$ (habitat use is not associated with either growth rates or predation rates) was tested against 2 alternatives, $H_{1}$ (because of their mobility, $F$. heteroclitus will move to habitats where growth rates can be increased; i.e. high growth rates will be observed in habitats used with higher frequency), and $\mathrm{H}_{2}$ (predator pressure restricts $F$. heteroclitus to habitats where growth rates are low; i.e. growth rates will be highest in habitats used with low frequency).

\section{STUDY SITES}

Three salt marshes (Spartina spp.) in the Narragansett Bay National Estuarine Reserve on Prudence Island, Rhode Island, USA (Fig. 1) were used as study area. All 3 marshes receive minimal freshwater input compared to the influx of marine water from tidal flow. The tidal range is approx. $1.5 \mathrm{~m}$. The salt marshes consist of 3 intertidal zones; upper intertidal-zone meadows of $S$. patens and Juncus gerardi, middle-zone monocultures of $S$. alterniflora, and low-zone areas devoid of vegetation except for occasional drift algae. 


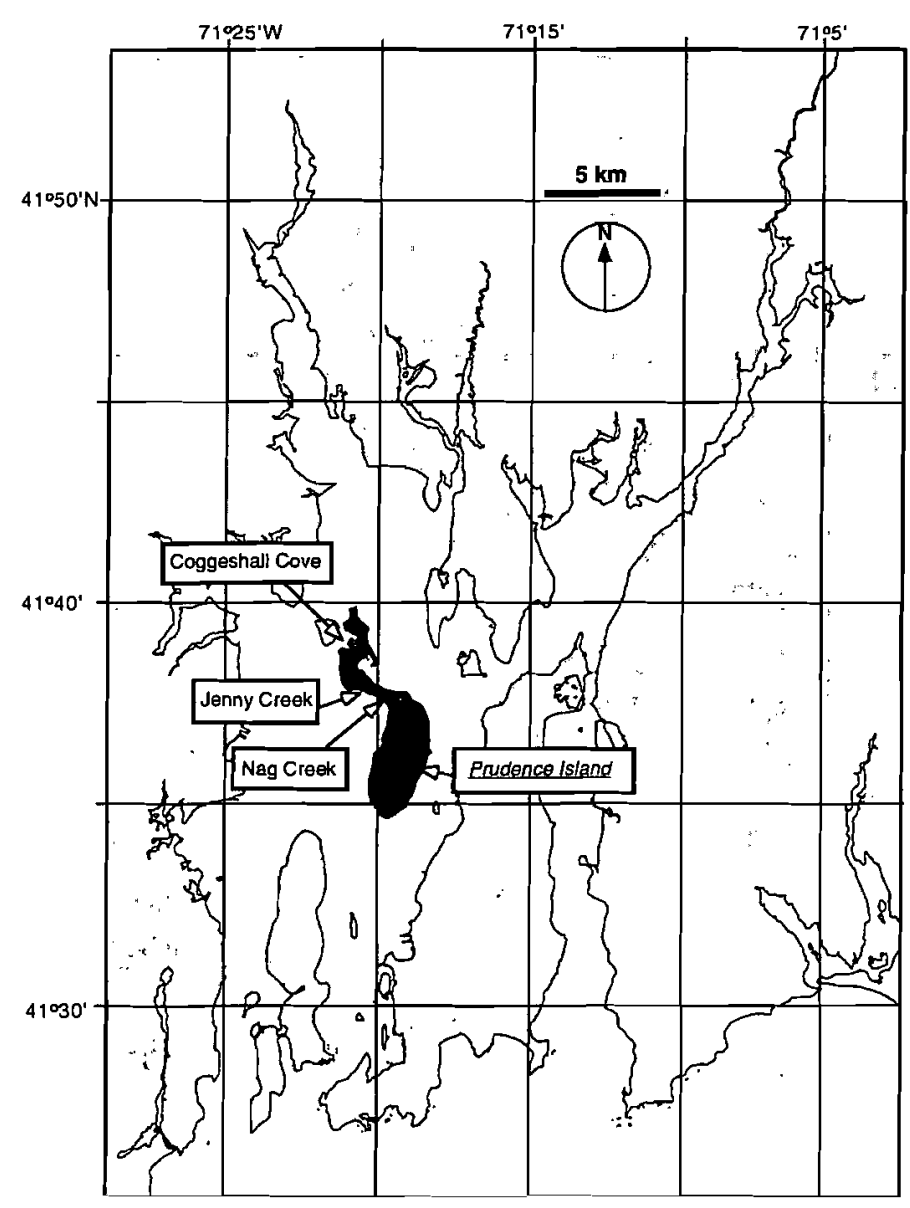

Fig. 1. Narragansett Bay, showing Prudence Island and locations of 3 marshes studied

All 3 salt marshes are bordered by barrier beaches. They differed in the types of habitat available (Table 1): (1) ponds, small areas in the marsh meadow that retain water at low tide; (2) creeks $<2 \mathrm{~m}$ across draining into channels or mudflats; (3) channels $>2 \mathrm{~m}$ across draining into mudflats or open water; (4) mudflats, large non-vegetated areas connected to the open water. Their habitat also varied in composition (Table 1):

Jenny Creek consists primarily of creeks connected to a long channel. The water flow in the creeks results from drainage of tidal water off the marsh meadow. Jenny Creek lacks ponds and a mudflat.

Nag Creek also contains creeks connected to a long channel ${ }_{i}$ it has many ponds and no mudflat.

Coggeshall Cove has a channel feeding into a large mudflat; it has many ponds. Unlike the other 2 marshes, there is very little creek habitat. Subtidal areas immediately adjacent to each marsh were also used for experimentation.
Table 1. Habitat types in Jenny Creek, Nag Cove, and Coggeshall Cove salt marshes

\begin{tabular}{|lcccc|}
\hline \multirow{2}{*}{ Study sites } & \multicolumn{4}{c|}{ Habitat types } \\
& Pond & Creek & Channel & Mudflat \\
\hline Jenny & No & Yes & Yes & No \\
Nag & Yes & Yes & Yes & No \\
Coggeshall & Yes & Little & Yes & Yes \\
\hline
\end{tabular}

\section{MATERIALS AND METHODS}

Habitat use. Habitat use of Fundulus heteroclitus was determined from capture rates obtained by placing minnow traps in each habitat in each marsh. This sampling was part of a larger multi-year study on habitat use of marshes by various fishes (Halpin unpubl. data). A subsample of the data relevant to the time period and sites of the other experiments was used for the present study. Minnow traps capture small fish and mobile invertebrates without harming them, except when environmental conditions become too stressful (e.g: sun at low tide in August). Traps were placed in all habitats at all 3 sites to compare capture rates among habitats and sites (Table 2). Traps were placed outside Nag Creek and Coggeshall Cove (one at each site) in summer, and one trap was placed outside Coggeshall Cove in the fall. Organisms caught within the traps were identified, counted, and released. Traps were placed in all habitats and sites, and were checked every $24 \mathrm{~h}$ for $3 \mathrm{~d}$ to reveal any day-to-day variation in fish habitat-use. All habitats were sampled at each sampling period. The average number counted for the $3 \mathrm{~d}$ sample was log-transformed to meet assumptions of normality and homoscedasticity. Normality of error terms was tested with JMP software (SAS Institute Cary, NC, USA), and homoscedasticity was tested by visual examination of residuals. Trapcapture was used as a dependent variable in an ANOVA with habitat, season, and habitat nested within site as factors. Because of the low sample numbers, the data from the traps outside the marsh were not included in the initial analyses, and were treated separately. Data from both seasons was pooled, and a nonparametric Kruskal-Wallis rank sum test was run using habitat as the factor, and the $3 \mathrm{~d}$ average trap-capture as the dependent variable.

Table 2. Number of traps placed in each site and habitat. When trap number differed between seasons of experiment, month and corresponding number of traps are given

\begin{tabular}{|lccccc|}
\hline Site & Pond & Creek & Channel & Mudflat & Outside marsh \\
\hline Jenny Creek & 0 & 4 (Aug) 7 (Nov) & 9 & 0 & 0 \\
Nag Creek & 3 & 3 (Aug) 4 (Nov) & 8 (Aug) 7 (Nov) & 0 & 1 (Aug) 0 (Nov) \\
Coggeshall Cove & 3 & 0 & 2 & 5 & 1 \\
\hline
\end{tabular}


Growth rates. To examine the effect of habitat on growth of Fundulus heteroclitus, they were penned inside cages in all habitats at all 3 sites in 2 different seasons. Three cages each were placed in the creek and channel habitats at Jenny Creek; pond, creek, and channel habitats in Nag Creek; and pond, creek, channel, and mudflat habitats at Coggeshall Cove. In addition, 3 cages were placed outside each site to determine growth rates outside of the mummichogs' normal distribution area. Minnow traps were placed in the cages to remove any stray fish captured in the cages during deployment. Cages were considered ready to use when no fish had been caught in them for $3 \mathrm{~d}$.

Ten Fundulus heteroclitus, 5 to $7 \mathrm{~cm}$ in length, were collected, individually tagged by subdermal injection of acrylic paint (Thresher \& Gronell 1978), anesthetized to prevent movement during photography, photographed, allowed to recover, and placed into each cage. Tagging allowed identification of individual fish at the start and end of each experimental run. Digitization of the photographs provided the exact initial total length of the fish. Anesthetized fish lay very flat and still on the photographic grid, allowing accurate assessment of length by digitization. At the end of the experiment, the fish were recaptured with baited minnow traps and re-photographed. Final total lengths were determined by digitizing the photographs, and growth rates were calculated as change in fish length $\left(\mathrm{mm} \mathrm{d}^{-1}\right)$.

The cages were $1 \mathrm{~m}$ square and constructed of knotless nylon netting, $0.635 \mathrm{~cm}$ mesh size (Memphis Net and Twine, TN, USA). The netting for each cage was tied onto four $1.9 \mathrm{~cm}$ diameter steel reinforcing bar ('rebar') poles which formed the 4 corners of the cage. Poles were 2.4 to $3.0 \mathrm{~m}$ long, i.e. scaled to a size that would prevent the tops of the cages being submerged at high tide. At the bottoms of the cages, $1 \mathrm{~m}$ of each pole was not attached to the mesh to allow the pole to be driven into the substrate, and $1 \mathrm{~m}$ of netting was left unattached to the poles to form a skirt that lay just under the surrounding substratum outside the cage.

In each habitat, the cages were deployed by driving the rebar poles into the substrate until the attached mesh skirt was flush with the substratum. The skirt was then buried under the sediment and secured in place by pinning lengths of pencil rebar where the cage walls met the substratum. Additional stakes ensured that the skirt was spread out around the cage and did not bunch up through sediment movement or other disturbance. The skirt prevented predators such as blue crabs from burrowing into the cage. This cage design allowed prey such as the shore shrimp Palaemonetes pugio to pass into the cage, and gave the mummichogs unrestricted access to the water surface and substratum.
The growth-rate experiment ran from 4 August to 20 September (summer) and again from 5/6 October to 16 November (fall) 1992. In the initial data-analysis, an ANCOVA was run with growth rate as the dependent factor. Habitat, season and site were used as independent factors, with habitat nested within site and initial fish length as the covariate. However, since the slopes of the regression lines within groups were not parallel, the residuals from the regression of initial size on growth for the whole data set were used as the dependent variable in an ANOVA and habitat, season and site as the independent factors in the final model, with habitat nested within site. Using the residuals as the dependent variable removes the confounding effect of non-parallel slopes and allows for more direct testing of the growth rates (Ramsey \& Schafer 1997). Homogeneity of variance was tested by visual inspection of residuals. To compare the growth of fish outside of sites with those within, a Student's $t$-test was performed on the residuals of fish caged outside of Coggeshall Cove with those caged within sites pooled over all habitats and sites.

Predation rate. I used tethering experiments to estimate the relative predation risk in each habitat. Six tethering poles were placed in pond and creek habitats at each site and in the shallow subtidal outside each site. Twelve tethering poles were placed in the channel habitat at Jenny Creek and Nag Creek and in the mudflat at Coggeshall Cove. In summer ( 2 runs, 6 and $5 d$, respectively) and fall ( 1 run of $8 \mathrm{~d}$ ) poles were placed in Jenny Creek (creek, channel), Nag Creek (pond, creek, channel), Coggeshall Cove (pond, channel, mudflat), and in subtidal areas just outside each site. The tethers were checked daily at each run. When a fish was missing from a tether it was scored as lost and replaced. The total number of days a fish remained on a tether was scored.

Individual Fundulus heteroclitus ( 5 to $7 \mathrm{~cm}$ size class) were tethered to $0.5 \mathrm{~m}$ of $8 \mathrm{lb}(3.64 \mathrm{~kg})$ test fishing line by either looping the line around the jaw with the aid of a needle, or by looping it through the mouth and out of the opercular flap. The other end of the line was attached to a $1.27 \mathrm{~cm}$ diameter PVC ring. The ring was slipped over a 2 to $2.5 \mathrm{~m}$ pencil rebar pole. The fish could swim around and up and down the pole. Preliminary observations indicated that the use of $>0.25 \mathrm{~m}$ long tethers, with $0.5 \mathrm{~m}$ long tethers used during the actual experiment, eliminated most major behavioral differences between tethered and untethered fish. Fish were able to feed and swim on the tether. Tethered fish could also hide under drift algae and burrow shallowly in the mud, escape behaviors often exhibited by untethered fish. Additionally, fish could avoid approaching green crabs Carcinus maenus when the tether was at least $0.25 \mathrm{~m}$ long. Green crabs could potentially attack tethered fish, although they are normally not known to feed on $F$. heteroclitus. The rebar pole ex- 
tended well above the water surface; a loop at the end prevented the PVC ring from slipping off the end of the pole. To minimize the risk of entanglement in vegetation, the mummichogs were tethered in creek areas where no Spartina alterniflora was present within the tether radius ( $1 \mathrm{~m}$ diameter). In all habitats, fish were so placed as to avoid entanglement in vegetation.

Controls were run in the field and laboratory. In the field, the fish were placed on tethers in unused growth cages, 1 fish per cage, in Rumstick Cove, Rhode Island (see Halpin 1997 for description) ( $n=3$ ) and Nag Creek $(n=6)$ for 10 and $14 d$, respectively. In the laboratory, they were tethered in aquaria $(n=10)$ for $2 \mathrm{wk}$. Additionally, fish $(n=10)$ were tethered in a flow tank (25 $\mathrm{cm} \mathrm{s}^{-1}$ current) separately for $24 \mathrm{~h}$ to determine if currents could pull them off their tethers. Since no fish were lost off tethers in any of the control groups, all fish missing from tethers in the field were considered to have been removed by a predator.

Since the mummichogs remained on their tethers until death or the end of the experimental run, the data can be analyzed with statistical techniques developed for survival data. In these experiments fish were either removed by predators or, if they survived the full duration of the experiment, by the investigator. Statisticians term data involving death and experimental termination by investigators 'uncensored' and 'censored', respectively. As my data included both uncensored and censored data, I tested for significant differences between all habitats using an extension of Gehan's generalized Wilcoxon test and the Kruskal-Wallis 1 -way analysis of variance by ranks for censored data (Lee 1980). Gehan's generalized Wilcoxon test is a nonparametric method for comparing censored survival distributions, whereby each observation in one sample is compared to each observation in a second sample and assigned a score. Once this score is calculated, an extension of the Kruskal-Wallis 1-way analysis of variance by ranks (analogous to the $F$-test in an analysis of variance) is used to compare multiple samples, using scores instead of original observations. This analysis tests against the null hypothesis that all the samples (here the tethering data from each habitat and site) are from the same distribution. According to the null hypothesis, the test statistic, $\chi^{2}$, has an approximately chi-squared distribution with $(K-1)$ degrees of freedom, where $K=$ the number of samples.

The product-limit estimate of the survival function $S(t)$ (Lee 1980) was calculated to allow graphical presentation of the tethering data. The survival function gives the probability of an individual surviving beyond time $t$ (e.g. at $t=0, S(t)=1$, when no survivors are left, then $S(t)=0)$. In this study, high values of $S(t)$ indicate low predator-encounter rates, and low values of $S(t)$ indicate high predator-encounter rates. The product- limit estimate of the survival function incorporates censored data in the calculation of $S(t)$.

Refuge use. To test the effect of predators on habitat use by Fundulus heteroclitus, I constructed predatorexclusion cages that provided refugia for $F$. heteroclitus from predators. Cage sides were cable-tied onto wooden poles and erected in the channel at Nag Creek. Three sides consisted of $\sim 3 \mathrm{~cm}$ vexar mesh, the channel bank constituted the fourth side, and the vexar mesh fitted snugly against the bank. Flaps of vexar mesh extended from 2 of the walls over the marsh surface to prevent predator entry across the marsh surface on very high tides. The exclosure cages were open at the top and bottom. The mesh was large enough for $F$. heteroclitus to move in and out of the exclosure areas, but most large predators were excluded. Cage controls were similar to experimental cages, but with strips of mesh removed to allow predator entry. Open controls were also set up, with poles marking the corners of where the cage would be. Three replicates each of cage treatment, cage control, and open control were used. The experiment was initiated in July 1993. In August 1993, traps were placed in the experimental areas, one trap per experimental area, for $5 \mathrm{~d}$ and checked every $24 \mathrm{~h}$ for presence of mummichogs. The results were analyzed by ANOVA, using fish captured as the dependent variable and treatment as the independent variable.

\section{RESULTS}

\section{Habitat use}

Habitat use by Fundulus heteroclitus varied significantly between habitats nested within sites on a seasonally-dependent basis (ANOVA; site(habitat) $\times$ season $\mathrm{p}=0.019$, $\mathrm{df}=4$ : Table 3 , Figs. $2 \& 3$ ). In summer, the creek and channel habitats at Jenny Creek, the creek habitat at Nag Creek, and the pond, channel and mudflat habitats and Coggeshall Creek were heavily used (Fig. 2). In the fall, the pond habitat at Coggeshall Cove and the creek habitat at Nag Creek were most heavily used, followed by creek habitat at Jenny Creek and the pond habitat at Nag Creek. The channel and mudflat habitats at Coggeshall Cove and the channel habitats at Jenny Creek and Nag Creek were not used heavily in the fall (Fig. 3).

Overall, habitat had a significant effect on trapcapture rate when the capture rates for traps outside the marshes were included (Kruskal-Wallis rank-sum test, $\mathrm{df}=4, \mathrm{p}<0.0001$ ). The mean scores for channel, mudflat and outside the marsh traps were less than the expected mean ([mean score - expected mean score]/ expected $\mathrm{SD}=-2.53,-1.75$, and -1.85 , respectively), 
Table 3. Fundulus heteroclitus. Results of analysis of variance testing effects of habitat, marsh and season on trap-captures. 'Significant at 0.05 level (see 'Results - Habitat use' for full details)

\begin{tabular}{|lccccc|}
\hline Source & df & SS & MS & $F$ & \multicolumn{1}{c|}{ p } \\
\hline Habitat & 3 & 0.041 & 0.138 & 4.0973 & 0.0962 \\
Season & 1 & 0.007 & 0.007 & 0.1722 & 0.6988 \\
Marsh (habitat) & 4 & 0.142 & 0.355 & 0.863 & 0.554 \\
Season $\times$ Inarsh (habitat) & 4 & 0.168 & 0.042 & 3.023 & $0.019^{*}$ \\
\hline
\end{tabular}

rates (as change in total length) were negative. In previous growth experiments with $F$. heteroclitus, Kneib (1981) also recorded negative growth rates in response to density-related food limitation. His data confirmed that changes in length reflect changes in dry biomass.

Growth rates of mummichogs caged outside the marsh did not

while the mean scores for the creek and pond habitats were greater than the expected mean score ([mean score - expected mean score]/expected SD $=3.95$ and 1.57, respectively). The scores for traps outside the marsh, channel, and mudflat habitats were therefore more similar to each other and lower in vaiue than the scores for the creek and pond habitats.

\section{Growth rates}

Growth rates of Fundulus heteroclitus varied significantly among habitats nested within sites (ANOVA, site(habitat) $p=0.0194, d f=5$, Table 4, Figs. $2 \& 3$ ), but not among sites or between seasons. There were significant interactions between habitat(site) and season (ANOVA, df $=4, \mathrm{p}<0.0001$ ), indicating that habitats differ from each other in a seasonally dependent fashion. As only one fish survived in creek cages in Jenny Creek, no growth rate could be calculated for that habitat at that site in summer. In some cases, growth

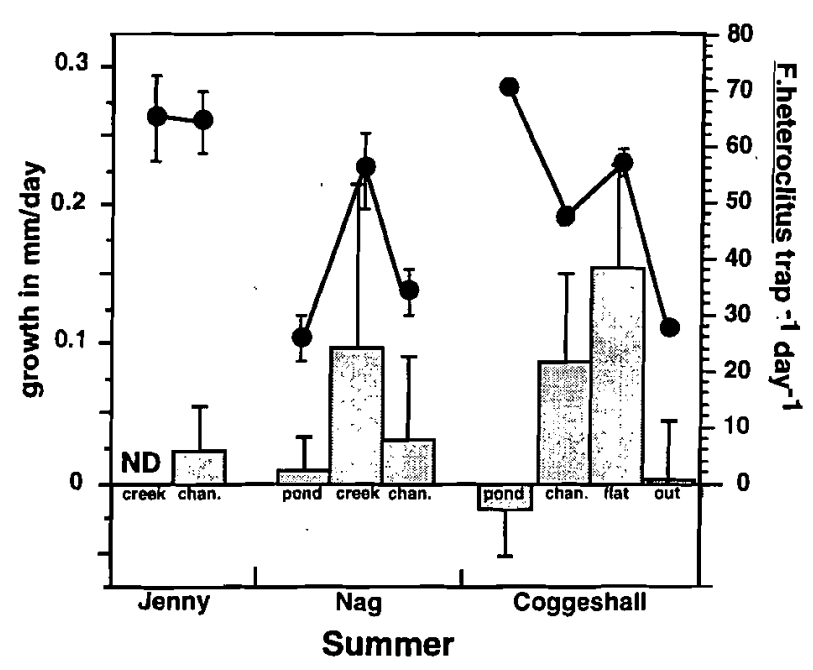

Fig. 2. Fundulus heteroclitus. Bars: average growth rate in each habitat and marsh in summer (Jenny Creek: creek $\mathrm{n}=0$, channel $n=23$; Nag Creek: pond $n=18$, creek $n=4$, channel $\mathrm{n}=13$; Coggeshall Cove: pond $\mathrm{n}=7$, channel $\mathrm{n}=11$, mudflat $\mathrm{n}=9$, outside marsh $\mathrm{n}=7$ ); line graphs: captures of $F$. heteroclitus. Error bars = $1 \mathrm{SE}$. ND: no data (poor survivorship) differ significantly from the combined growth rates recorded for fish cages within the marsh in either season. However, the habitat displaying highest fish growth was always inside a marsh (Figs. 2 \& 3). The cages outside Jenny Creek and Nag Creek were all damaged by storms, and the fish within them escaped. The cages outside Coggeshall Cove retained their fish, so I used these individuals to obtain a general estimate of growth rates in non-intertidal habitats.

With one exception, summer growth rates followed the patterns of habitat use very closely in summer (Fig. 2). At Jenny Creek, fish in the channel habitat grew very little, and the extremely poor survivorship in the creek cages indicate that neither habitat represents a good area for fish energetically. Capture rates were approximately equal in each habitat. In Nag Creek, large positive growth rates in creek habitats corresponded with heavy habitat use, and low growth rates within ponds and

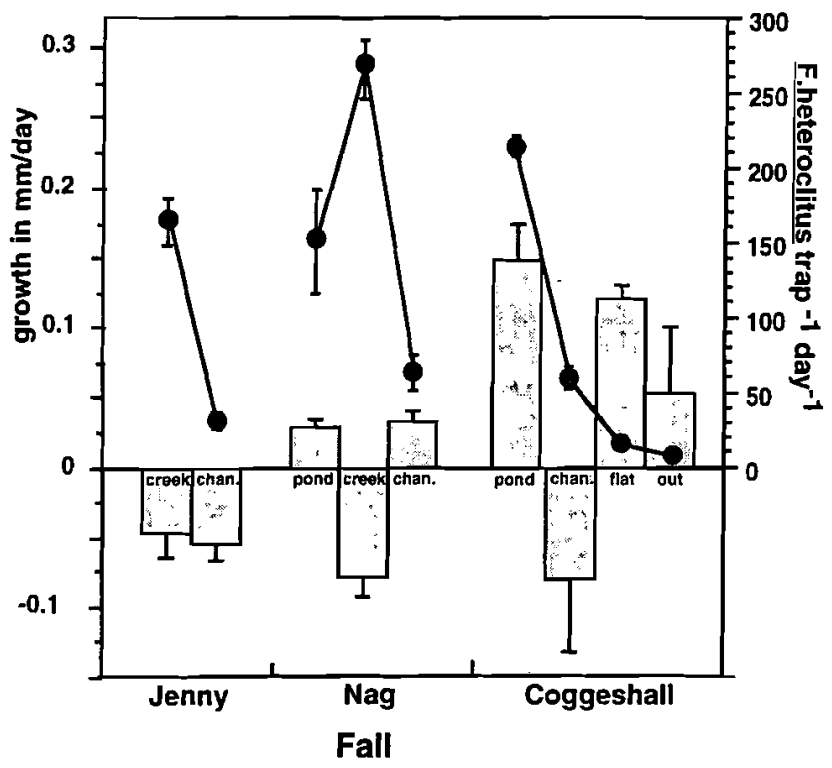

Fig. 3. Fundulus heteroclitus. Bars: average growth rate in each habitat and marsh in fall (Jenny Creek: creek $n=10$, channel $n=24$; Nag Creek: pond $n=17$, creek $n=10$, channel $n=16$; Coggeshall Cove: pond $n=14$, channel $n=6$, mudflat $n=15$, outside marsh $n=4$ ); line graphs: average capture of $F$. heteroclitus. Error bars $=1 \mathrm{SE}$ 
Table 4. Fundulus heteroclitus. Results of analysis of variance testing effects of habitat, marsh and season on residuals of regression of mummichog growth on initial size. -Significant (see 'Results - Growth rates' for full details)

\begin{tabular}{|lcclcc|}
\hline Source & df & SS & MS & $F$ & p \\
\hline Marsh & 2 & 0.138 & 0.069 & 1.984 & 0.2321 \\
Season & 1 & 0.005 & 0.005 & 0.427 & 0.5144 \\
Habitat (marsh) & 5 & 0.173 & 0.35 & 2.772 & 0.0194 \\
Marsh $\times$ season & 2 & 0.016 & 0.008 & 0.079 & 0.9254 \\
Habitat(marsh) $\times$ season & 4 & 0.415 & 0.104 & 8.292 & $0.0001^{\circ}$ \\
Residual & 182 & 2.276 & 0.013 & & \\
\hline
\end{tabular}

rates, with capture nearly zero. Fish in both creek and channel habitats in Jenny Creek exhibited low growth rates in fall. However, habitat use was higher in creeks.

\section{Predation rate}

Survival times on tethers differed significantly among marsh habitats in both summer $\left(\chi^{2}=\right.$ channels corresponded with low habitat use. At Coggeshall Cove, Fundulus heteroclitus caged in mudflat habitat and channel habitats displayed high growth rates, and these habitats had high trap-captures. Ponds at Coggeshall Cove constituted the only marsh habitat where use did not reflect growth rates. F. heteroclitus in Coggeshall Cove ponds had very low growth rates, but the capture data reveals these habitats were used more heavily than habitats in the same site with higher growth rates. $F$. heteroclitus caged outside the marsh had zero growth and corresponding low captures.

In fall, the correspondence between habitat use and growth rates was much weaker (Fig. 3). At Nag Creek, growth rates were lowest and trap-capture highest in creek habitats. Conversely, Fundulus heteroclitus in the pond and channel habitats had low but positive growth rates and lower captures than those in creeks. In Coggeshall Cove, high growth rates we associated with high capture rates in ponds and low growth rates with low capture rates in channels. Mummichogs in the mudflat cages in Coggeshall displayed high growth rates although few were trapped there; mummichogs outside the marsh displayed low but positive growth
98.76, $\mathrm{p}<0.05, \mathrm{df}=10, \mathrm{n}=463, K=11)$ and fall $\left(\chi^{2}=\right.$ $41.69, \mathrm{p}<0.05, \mathrm{n}=242, K=11$ ). In summer, predation rates were high in every habitat at every site except for ponds in Coggeshall Cove (Fig. 4), indicating that predators are rarely encountered in pond habitats at Coggeshall Cove. Accordingly, ponds are the most intensively used habitat at Coggeshall Cove in the summer, even more heavily used than those habitats in which fish exhibited higher growth rates (Fig. 2). Interestingly, the ponds at Nag Creek apparently did not offer the same refuge from predation as ponds at Coggeshall Cove (Fig. 4).

In fall, predation was much lower overall than in summer (Fig. 5). Areas outside the marshes always displayed the highest predator-encounter rate. Ponds at Coggeshall Cove still had the lowest predator encounter rate for tethered fish of any habitat. In the fall, ponds also had the highest growth rates in Coggeshall Cove, and were used almost exclusively by Fundulus heteroclitus (Fig. 4). At Nag Creek, both pond and creek habitats had low predation rates, followed by channel habitats, but only the creeks were heavily used (Fig. 3). At Jenny Creek, predation was similar
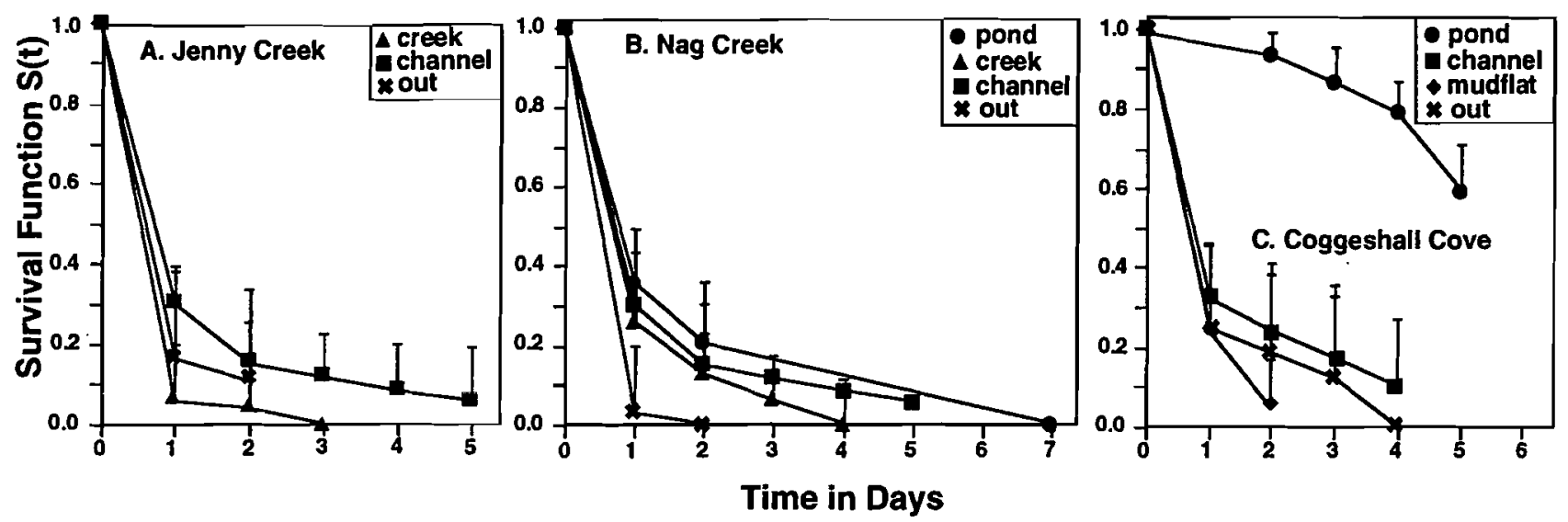

Fig. 4. Fundulus heteroclitus, Survival function, $S(t)$ (i.e. probability of individual surviving beyond time $t$ ) for each habitat type vs time in days for fish tethered during summer in (A) Jenny Creek marsh (Day 1: creek $n=50$, channel $n=65$, outside marsh $n=18$ ), (B) Nag Creek marsh (Day 1: pond $n=34$, creek $n=47$, channel $n=80$, outside marsh $n=35$ ) (C) Coggeshall Cove (Day 1 :pond $n=18$, channel $n=37$, mudflat $n=72$, outside marsh $n=16$ ). Error bars $=1 \mathrm{SE}$ 

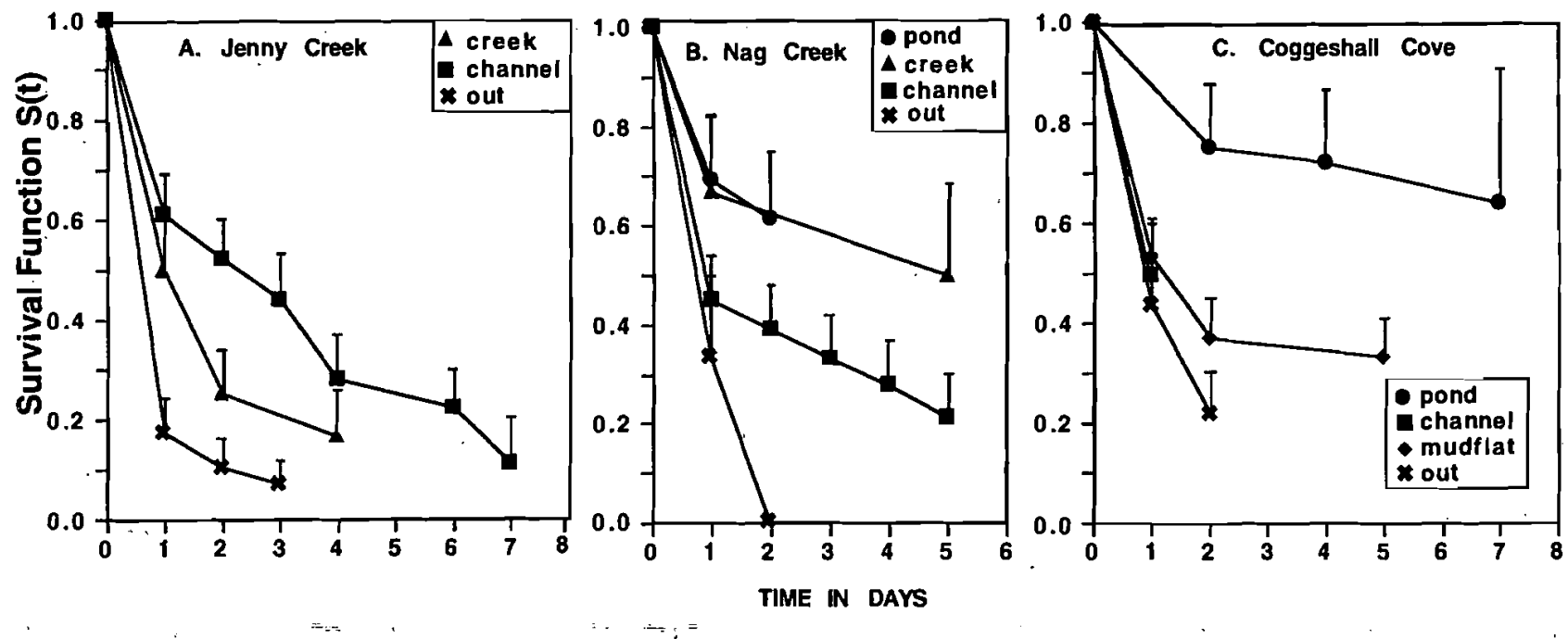

Fig. 5. Fundulus heteroclitus. Survival function $S(t)$ for each habitat type vs time in days for fish tethered during fall in (A) Jenny Creek marsh (Day 1: creek $n=24$, channel $n=36$, outside marsh $n=29),(B)$ Nag Creek marsh (Day 1: pond $n=13$, creek $n=9$, channel $n=31$, outside marsh $n=12$ ) (C) Coggeshall Cove (Day 1: pond $n=12$, channel $n=17$, mudflat $n=37$, outside marsh $\mathrm{n}=23$ ). Error bars $=1 \mathrm{SE}$

between creek and channel habitats. Only creeks were heavily used at Jenny Creek, although no clear growth or predator refuge emerged (Fig. 5). F. heteroclitus tethered outside the marsh were always quickly lost.

\section{Refuge use}

Fundulus heteroclitus used exclosure areas preferentially to non-exclosure areas. Trap-captures of $F$. heteroclitus were higher in predator-exclosure areas than in either cage controls or open controls $(p<0.001)$ (Fig. 6).

\section{DISCUSSION}

This study demonstrates that the population dynamics of mummichogs, Fundulus heteroclitus, which are mobile intertidal animals, differ from those of sessile intertidal organisms. Adults altered their habitat use on a seasonal basis in response to environmental changes. In salt marshes, habitat use is affected by a fish's ability to grow and escape predation relative to other available habitats. $F$. heteroclitus alters its habitat-use patterns to maximize growth when predator-encounter rates are high in all available habitat types. Faced with a trade-off choice between predator avoidance and growth, the mummichogs used habitats offering predator refuge, such as ponds, more heavily. In one instance, fish were found both growth advantages and predator refuge in a single habitat-Coggeshall Cove ponds in fall-resulting in the almost exclusive use of this habitat at that time.
Fundulus heteroclitus exhibit strong seasonal changes in habitat use (Halpin 1997). Previous work revealed that habitat type, month of sampling, and site sampled all interact to affect habitat use in $F$. heteroclitus (Halpin unpubl. data). This suggests that adult mummichogs can perceive and respond to habitat changes by adjusting use-patterns within marshes and between habitats. Highly mobile animals may respond to environmental change by abandoning a habitat permanently or temporarily, but without the mortality associated with sessile communities (Karr \& Freemark 1985, Breitburg 1992). In mummichog populations, individuals may abandon habitats within marshes, but may not move the long distances required to travel between marshes (Lotrich 1975). However, habitat use alone does not reflect overall habitat quality, as the

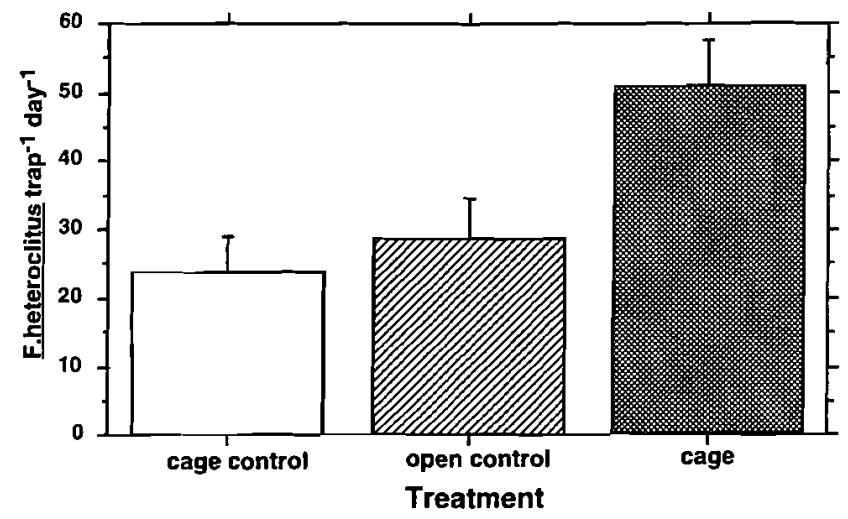

Fig. 6. Fundulus heteroclitus. Average captures trap $\mathrm{p}^{-1} \mathrm{~d}^{-1}$ in exclosure cages, cage controls and open control areas. Error bars $=1 \mathrm{SE}$ 
habitat use reflects the relative, not absolute, benefits of the habitat in comparison to other available habitats. Costs and benefits such as growth advantages and predation risk must be measured to determine habitat quality, since fish may heavily use 'poor' habitats in one site if all other available habitats are also of poor quality.

The influence of growth rates on habitat use was most apparent in the summer (Fig. 2). At a time when predation rates were high in almost all habitats, the fish used habitats in which growth was enhanced. At Jenny Creek and Nag Creek sites and in all habitats except ponds at Coggeshall Cove, fish habitat-use closely paralleled growth rates. In the fall, habitat-use patterns did not parallel growth rates, except for heavy use of the ponds at Coggeshall Cove. Growth rate may be influenced by a number of factors, both biotic and physical, such as food availability, heat stress, and oxygen depletion. This study suggests that mummichogs perceive those environmental variables that are responsible for growth, and alter their habitat use accordingly. Because habitat quality, as reflected by high growth rates, varied between sites on a seasonal basis, fish would gain by responding directly to environmental variables that influence growth, since those variables might not be consistent within a particular habitat or site.

On a larger scale, overall growth rates of Fundulus heteroclitus in intertidal areas did not differ from those in the subtidal, though the highest recorded growth rates were always within the intertidal areas (Figs. $2 \& 3$ ). This is in marked contrast to growth patterns of many, but not all, sessile intertidal animals and plants, which display higher growth rates with increasing depth. Typically, in these cases, such organisms are excluded from high growth rate areas by strong negative interactions with other organisms (Connell 1961, 1972, Dayton 1971, Paine 1977, Menge et al. 1994). Since recorded predation rates were also high outside the marshes in both seasons, $F$. heteroclitus obviously would gain little by straying outside its normal range unless to travel to a more profitable marsh.

Many studies have shown the risk of predation to influence patch-choice in foraging fish (Power 1984, Milinski 1986, Holbrook \& Schmitt 1988a,b, Werner \& Hall 1988, Gotceitas et al. 1995, Persson \& Eklov 1995). Faced with a trade-off choice between high and low predation risk, fish tend to choose lower predation risk over higher food reward (Werner et al. 1983, Power 1984, Holbrook \& Schmitt 1988a). In this study, when low-predation habitats were created, as in the exclosure experiment, fish used them more heavily than control habitats with higher predation. Also, Fundulus heteroclitus faced a trade-off between high predatorencounter rates and growth at Coggeshall Cove in summer (Figs. $2 \& 4$ C). Habitat use was high in ponds (Fig. 2), which offer refuge from predators (Fig. 4c) but may compromise growth (Fig. 2). This supports previous work (Werner et al. 1983, Power 1984, Holbrook \& Schmitt 1988) on patch-choice in various fishes. I observed an unusual seasonal shift in the use of the ponds at Coggeshall Cove that minimized trade-offs between growth and predator avoidance: when Coggeshall Cove ponds offered both a predator refuge and high growth rates (Figs. $3 \& 5 \mathrm{C}$ ), F. heteroclitus used that habitat almost exclusively (Fig 3 ).

Predation risk within marshes declined in the fall, but remained high outside the marshes. In all sites in fall, most ponds and creeks exhibited lower predatorencounter rates. In Jenny Creek, however, predatorencounter rates in the creeks were not much lower than in the channel habitats. In the fall, mummichogs used creeks heavily, although these did not offer a distinct advantage in predator avoidance or growth over other available habitats (Figs. $3 \& 5$ ). Although this study has identified 2 major influences on habitat use by Fundulus heteroclitus, the explanation for preferential creek use is not clear. Creeks may provide a better predator refuge than the present data reveal.

Predation has been inferred to be an important factor determining habitat use in Fundulus heteroclitus juveniles and adults (Kneib 1987, McIvor \& Odum 1988) Kneib (1987) showed that juvenile $F$. heteroclitus will recruit to intertidal zones below their normal distribution range after exclusion of adult $F$. heteroclitus, their chief predator. In the absence of adults, juvenile survivorship was enhanced in zones deeper than their normal range. Adult $F$. heteroclitus are preyed upon by the blue crab Callinectes sapidus, the bluefish Pomatamus saltatrix, and the weakfish Cynoscion regalis (Bigelow \& Schroeder 1953, Kneib 1982), all of which forage in marshes at high tide. Predator-encounter rates at flood-tide can be high in marshes (McIvor \& Odum 1988). The present study has confirmed that marshes comprise important refuges from predation for small fishes. More study on how habitats vary in refuge potential within and between marshes is necessary to discover the mechanisms underlying predatorprey interactions in salt marshes.

Tethering has been heavily used in studies to assess relative predator-encounter rates with mobile prey (Shulman 1985, Witman 1985, McIvor \& Odum 1988, Aronson 1989, Wilson et al. 1990). Recent criticism of tethering as an experimental technique (Peterson \& Black 1994, Zimmer-Faust et al. 1994) has centered on 3 issues: (1) lack of correspondence between natural and tethered predation-rates (Peterson \& Black 1994, Curran \& Able 1998); (2) modification of prey escaperesponses, with the result that tethered animals may be taken from the tether by predators they would nor- 
mally avoid (Zimmer-Faust et al. 1994); (3) interactions between tethering and habitat effects that are not considered, termed 'second-order artifacts' (Peterson \& Black 1994, Curran \& Able 1998). Second-order artifacts can result when the habitat interferes with the behavior of tethered prey, e.g. by entanglement in vegetated areas and non-entanglement in open areas.

I believe that the data on tethered mummichogs gathered in this study are informative, and will address the above criticisms briefly: (1) While tethering does not directly measure predation rates of a natural population, it can provide a relative measurement of the predation risks associated with certain habitat types. For example, a $90 \%$ loss of a tethered organism does not mean that $90 \%$ of an untethered population would be lost to predation. However, when one habitat displays $90 \%$ loss and another habitat displays $10 \%$ loss, there is obviously a greater risk of predation in the former habitat than in the latter. (2) In this study, the use of long tethers $(>0.25 \mathrm{~m}$ ) eliminated most major behavioral differences between tethered and untethered fish (see 'Materials and methods - Predation rate'); therefore, the major effect of the tethering was that intended, i.e. restriction of overall mobility. (3) Two secondorder artifacts are pertinent to this study: (i) differential potential for entanglement in vegetation between habitats, and (ii) large differences in predator behavior between habitats. (i) In all habitats care was taken to avoid potential entanglement of tethered fish. (ii) The blue fish Pomatamus saltatrix and the blue crab Callinectes sapidus were the most common predators, both being fast-moving predators that primarily prey on fishes and shrimp. Between-predator artifacts are most common when predators differ greatly in behavior, e.g. the behavioral patterns of fishes or crabs compared to that of seastars (Barbeau \& Scheibling 1994). Since blue fishes and blue crabs have similar diets and predatory behavior, behavioral differences should therefore have had no greater influence than that arising from natural variation. Also, as pointed out by Peterson \& Black (1994), separation of predator-habitat interactions in such a situation can be impossible.

In this study, habitat quality also differed between sites in terms of both growth rates and predator refuge. Ponds at Coggeshall Cove differed in both growth rates and tether losses from ponds at Nag Creek. At both sites, some ponds are connected by small creeks to mudflats and channels; this may increase access by predators and account for some differences in predation rates between ponds. In those ponds that were not connected by creeks to other habitats, predators seemed to be better able to penetrate into ponds at Nag Creek than at Coggeshall Cove. During the study, blue crabs were observed in closed ponds at Nag Creek, but not at Coggeshall Cove. Differences be- tween sites do not necessarily arise from differences in the types of habitat available, but also from the overall quality of those habitats. Further experimental work is necessary to elucidate how and why sites differ in overall habitat quality.

Differences in overall habitat quality could contribute to differences in overall marsh quality through variation in the type and abundance of habitats available. For example, some habitats in Coggeshall Cove displayed high growth rates and low predator encounter rates in summer and fall, but these were not always the same habitats (Figs. 2, 3, 4C \& 5C). Also, Coggeshall Cove ponds in fall comprised the only habitat in any season or site providing both high growth rates and shelter from predation (Figs. $3 \& 5 \mathrm{C}$ ). Thus, fish at Coggeshall Cove always had access to nabitats that of fered either high growth rates or low predation rates. Conversely, caged fish in all habitats at Jenny Creek never exhibited a strongly positive growth rate, and they disappeared quickly from tethers compared to other sites (Figs. 2, 3, 4A \& 5A). These data suggest that fish in a site comprised of poor-quality habitats such as Jenny Creek might profit by dispersing to a site higher-quality habitats such as Coggeshall Cove, depending on the risks of migration from marsh to marsh in relation to the potential benefit (Morris 1987). However, evidence suggests that Fundulus heteroclitus do not move long distances as adults (Fritz et al. 1975, Lotrich 1975), juveniles, or larvae, since this species undergoes direct development from eggs deposited on the marsh surface, and predation by adults restricts juveniles to high-zone areas (Kneib 1987). Tagging studies of between-marsh dispersal might reveal the extent to which $F$. heteroclitus switches marshes.

In summary, both predation risk and growth influences habitat use by Fundulus heteroclitus in intertidal salt marshes. Overall, salt marshes provide both shelter and the potential for growth, but the fish must often compromise between the 2 in certain habitat types. Predation risk takes primary importance in determining habitat use by $F$. heteroclitus; therefore this species cannot be considered to conform to the ideal free distribution (IFD) pattern. However, when predation rates are consistently high across habitats, growth rates play an important part in determining habitat use, in conformity with IFD predictions. Because the fish must often choose between habitats of poor quality, profitability of a habitat for this species cannot be assessed by degree of habitat use alone, but must take into consideration factors such as growth and predation risk that influence habitat quality. Future studies could focus on why habitats vary in growth and refuge potential between sites. 
Acknowledgements. I wish to thank M. D. Bertness and S. D. Gaines for their support and advice. This manuscript was improved by comments from S. D. Gaines, M. D. Bertness, A. Hines, D. Morse, G. E. Goslow, and B. A. Menge. N. Zarday, D. Rudnick, N. Beckel, A. Seltz, A. Doherty, and M. Godino assisted with field work. I am grateful to A. Beck and P. Hebert of the Prudence Island Reserve. This work was supported by NSF Grants OCE 89-16841 to S. D. Gaines and M. D. Bertness, BSR-85-16992 and BSR-89-06354 to M. D. Bertness, Rhode Island Department of Environmental Management Grant to S. D. Gaines, M. D. Bertness and P.M.H.; grants from the International Woman's Fishing Society and the Lerner Gray Fund for Marine Research to P.M.H.; and an Andrew W. Mellon Foundation grant to J. Lubchenco and B. A. Menge.

\section{LITERATURE CITED}

Aronson RB (1989) Brittlestar beds: low predation anachronisms in the British Isles. Ecology 70:856-865

Barbeau MA, Scheibling RE (1994) Procedural effects of prey tethering experiments: predation of juvenile scallops by crabs and sea stars. Mar Ecol Prog Ser 111:305-310

Bigelow HB, Schroeder WC (1953) Fishes of the Gulf of Màine. Fish Bull US 53:162-164

Boesch DB, Turner RE (1984) Dependence of fishery species on salt marshes: the role of food and refuge. Estuaries 7: $460-468$

Bozeman EL, Dean JM (1980) The abundance of estuarine larval and juvenile fish in a South Carolina intertidal creek. Estuaries 3:89-97

Breitburg DL (1992) Episodic hypoxia in Chesapeake Bay: interacting effects of recruitment, behavior, and physical disturbance. Ecol Monogr 62:525-546

Connell JH (1961) The influence of interspecific competition and other factors on the distribution of the barnacle Chthamalus stellatus. Ecology 42:710-723

Connell JH (1972) Community interactions on rocky intertidal shores. Annu Rev Ecol Syst 31:169-192

Curran MC, Able KW (1998) The value of tethering fishes (winter flounder and tautog) as a tool for assessing predation rates. Mar Ecol Prog Ser 163:45-51

Dayton PK (1971) Competition, disturbance, and community organization: the provision and subsequent utilization of space in a rocky intertidal community. Ecol Monogr 41: 351-389

Fretwell SD, Lucas HL (1970) On terrestrial behaviour and other factors influencing habitat distribution in birds. Acta Biotheor 19:16-36

Fritz ES, Meredith WH, Lotrich VA (1975) Fall and winter movements and activity level in the mummichog, Fundulus heteroclitus, in a tidal creek. Chesapeake Sci 16: 211-215

Gibson RN (1969) The biology and behavior of littoral fish. Oceanogr Mar Biol Annu Rev 7:367-410

Gotceitas V, Fraser S, Brown JA (1995) Habitat use by juvenile Atlantic cod (Gadus morhua) in the presence of an actively foraging and non-foraging predator. Mar Biol 123: $421-430$

Halpin PM (1997) Habitat use patterns of the mummichog, Fundulus heteroclitus, in New England: I. Intra-marsh variation. Estuaries 20:618-625

Holbrook SJ, Schmitt RJ (1988a) The combined effects of predation risk and food reward on patch selection. Ecology 69:123-134

Holbrook SJ, Schmitt RJ (1988b) Effects of predation risk on foraging behavior: mechanisms altering patch choice. J Exp Mar Biol Ecol 121:151-163

Jefferies MJ, Lawton JH (1984) Enemy free space and the structure of ecological communities. Biol J Linn Soc 23 : 269-286

Karr JR, Freemark KE (1985) Disturbance and vertebrates: an integrative perspective. In: Pickett STA, White PS (eds) The ecology of natural disturbance and patch dynamics. Academic Press, Orlando, FL, p 153-168

Kneib RT (1981) Size specific effects of density on the growth, fecundity, and mortality of the fish Fundulus heteroclitus in an intertidal salt marsh. Mar Ecol Prog Ser 6:203-212

Kneib RT (1982) The effects of wading birds (Ardeidae) and blue crabs (Callinectes sapidus) on the population size structure of the common mummichog, Fundulus heteroclitus. Estuar Coast Shelf Sci 14:159-165

Kneib RT (1987) Predation risk and habitat usage of intertidal habitats by young fish and shrimp. Ecology 68:379-386

Kneib RT, Stiven AE (1978) Growth, reproduction, and feeding of Fundulus heteroclitus (L.) on a North Carolina salt marsh. J Exp Mar Biol Ecol 31:121-140

Lee ET (1980) Statistical methods for the analysis of survival data. Lifetime Learning Publications, Belmont, CA

Lewis JR (1963) The ecology of rocky shores. English Universities Press, London

Lima SL, Dill LM (1990) Behavioral decisions made under the risk of predation: a review and prospectus. Can J Zool 68: 619-640

Lotrich VA (1975) Summer home range and movements of Fundulus heteroclitus (Pisces: Cyprinodontidae) in a tidal creek. Ecology 56:191-198

McIvor CC, Odum WE (1988) Food, predation risk, and microhabitat selection in a marsh fish assemblage. Ecology 69 1341-1351

Menge BA, Berlow EG, Blanchette CA, Navarrete SA, Yamada SB (1994) The keystone species concept: variation in interaction strength in a rocky intertidal habitat. Ecol Monogr 64:249-286

Menge BA, Sutherland JP (1987) Community regulation: variation in disturbance, competition, and predation in relation to environmental stress and recruitment. Am Nat 130: $730-757$

Milinski M (1986) Constraints placed by predators on feeding behaviour. The behaviour of teleost fishes. Croom Helm, London, p 253-274

Morris DW (1987) Spatial scale and the cost of density-dependent habitat selection. Evol Ecol 1:379-388

Newell RC (1979) Biology of intertidal animals. Marine Ecological Surveys Ltd., Kent

Nixon SW, Oviatt CA (1973) Ecology of a New England salt marsh. Ecol Monogr 43:463-98

Paine RT (1977) Controlled manipulations in the marine intertidal zone, and their contributions to ecological theory. The changing scenes in natural sciences 1776-1976. Spec Publ Acad Nat Sci Phila 12:245-270

Peckarsky BL, Cowan CA, Penton MA, Anderson C (1993) Sublethal consequences of stream-dwelling predatory stoneflies on mayfly growth and fecundity. Ecology 74: $1836-1846$

Persson L, Eklov P (1995) Prey refuges effecting interactions between piscivorous perch and juvenile perch and roach. Ecology 76:70-81

Peterson CH, Black R (1994) An experimentalist's challenge: when artifacts of intervention interact with treatments. Mar Ecol Prog Ser 111:289-297

Power ME (1984) Depth distributions of armored catfish: predator-induced resource avoidance? Ecology 65:523-528 
Ramsey FL, Schafer DW (1997) The statistical sleuth. Wadsworth Publishing Co, Bellmont, CA

Rogers SG, Targett TE, Van Sant SB (1984) Fish-nursery use in Georgia salt marsh estuaries: the influence of springtime freshwater conditions. Trans Am Fish Soc 113:595-606

Shulman MJ (1985) Recruitment of coral reef fishes: effects of distribution of predators and shelter. Ecology 66:1056-1066

Thresher RE, Gronell AM (1978) Subcutaneous tagging of small reef fishes. Copeia 1978:352-353

Tregenza T (1995) Building on the ideal free distribution. Adv Ecol Res 26:253-307

Turner AM (1996) Freshwater snails alter habitat use in response to predation. Anim Behav 51:747-756

Underwood AJ, Denley EJ (1984) Paradigms, explanations, and generalizations in models for the structure of intertidal communities on rocky shores. In: Strong DR, Simberloff $D$, Abele $L$, Thistle A (eds) Ecological communities: conceptual issues and the evidence. Princeton University Press, Princeton, NJ, p 151-180

Underwood AJ, Denley EJ, Moran MJ (1983) Experimental analyses of the structure and dynamics of mid-shore rocky intertidal communities in New South Wales. Oecologia 56: 202-219

Walls M, Kortelainen I, Sarvala J (1990) Prey responses to fish predation in freshwater communities. Ann Zool Fenn 27: 183-199

Weinstein MP (1979) Shallow marsh habitats as primary nurseries for fishes and shellfish, Cape Fear River, North Carolina. Fish Bull US Natn Mar Fish Serv 77:339-357

Editorial responsibility: Otto Kinne (Editor),

Oldendorf/Luhe, Germany
Weisberg SB (1986) Competition and coexistence among four estuarine species of Fundulus. Am Zool 26:249-257

Weisberg SB, Lotrich VA (1982) Ingestion, egestion, excretion, growth and conversion efficiency for the mummichog, Fundulus heteroclitus (L.). J Exp Mar Biol Ecol 62: $237-249$

Weisberg SB, Lotrich VA (1986) Food limitations of a Delaware salt marsh population of the mummichog, Fundulus heteroclitus. Oecologia 68:168-173

Werner EE, Gilliam JF, Hall DJ, Mittelbach GG (1983) An experiment test of the effects of predation risk on habitat use in fish. Ecology 64:1540-1548

Werner EE, Hall DJ (1988) Ontogenetic habitat shifts in bluegill: the foraging rate predation risk tradeoff. Ecology 69:1352-1366

Wilson KA, Able KW, Heck KL (1990) Predation rates on juvenile blue crab in estuarine nursery habitats: evidence for the importance of macroalgae (Ulva lactuca). Mar Ecol Prog Ser 58:243-251

Witman JD (1985) Refuges, biological disturbance, and rocky subtidal community structure in New England. Ecol Monogr 55:421-445

Wright JH (1972) Growth, mortality, production and consumption of a population of the salt marsh killifish, Fundulus heteroclitus Linnaeus. Master's thesis. Boston University, Boston, MA

Zimmer-Faust RK, Fielder DR, Heck KL Jr, Coen LD, Morgan SG (1994) Effects of tethering on predatory escape by juvenile crabs. Mar Ecol Prog Ser 111:299-303

Submitted: February 6, 1998; Accepted: October 20, 1999 Proofs received from author(s): May 19, 2000 